Article

\title{
Ion-Molecule Reactions and Chemical Composition of Emanated from Herculane Spa Geothermal Sources
}

\author{
Constantin Cosma ${ }^{1}$, Ioan Suciu ${ }^{1}$, Lorentz Jäntschi ${ }^{2}$ and Sorana D. Bolboacă ${ }^{2,3, *}$ \\ ${ }^{1}$ Babeş Bolyai University, Faculty of Environmental Science, 1 M. Kogălniceanu, 400084 Cluj- \\ Napoca, Romania; E-mail(s): cosmac@enviro.ubbcluj.ro; siiioan@yahoo.com \\ 2 Technical University of Cluj-Napoca, 103-105 Muncii Bvd, 400641 Cluj-Napoca, Romania; \\ E-mail: lori@academicdirect.org \\ ${ }^{3}$ Iuliu Haţieganu University of Medicine and Pharmacy Cluj-Napoca, Department of Medical \\ Informatics and Biostatistics, 6 Louis Pasteur, 400349 Cluj-Napoca, Romania.
}

* Author to whom correspondence should be addressed; E-mail: sbolboaca@umfcluj.ro; Tel.: +4-0264-431697; Fax: +4-0264-593847

Received: 3 May 2008; in revised form: 3 June 2008 / Accepted: 4 June 2008 / Published: 20 June 2008

\begin{abstract}
The paper presents a chemical composition analysis of the gases emanated from geothermal sources in the Herculane Spa area (Romania). The upper homologues of methane have been identified in these gases. An ion-molecule reaction mechanism could be implicated in the formation of the upper homologues of methane. The $\mathrm{CH}_{4}{ }^{+}$ions that appear under the action of radiation are the starting point of these reactions. The presence of hydrogen in the emanated gases may be also a result of these reactions.
\end{abstract}

Keywords: Ion-molecule reactions, Radioactivity, Methane, Methane upper homologues.

\section{Introduction}

Herculane Spa (Aqua Hercilis, lat.) is a town in Caraş-Severin County, Romania. It is situated at an altitude of $165 \mathrm{~m}$ in the Cerna River valley, between Mehedinţi (to the east) and Cerna Mountains (to the west). The Romans discovered the curative value of the thermal mineral waters found in Herculane 
Spa almost 2,000 years ago. It is one of the oldest health resorts in Romania and one of the oldest in the world, being renowned for its eighteen thermal mineral water springs. Three different types of thermal mineral water with different hydrogeological origins are identified in this area [1]: (a) cold water, (b) hot water (deep cold waters that are thermalized), and (c) thermal mineral water.

The thermal mineral waters from Herculane Spa are used in treatment of rheumatic [2], neurological [3], gynaecological [4] and dermatological diseases [5], or for rehabilitation of posttraumatic patients [6]. The geothermal waters from Herculane Spa have their origin in granites and sedimentary rocks (marls and limestone), the latter forming the impermeable roof of the hydrothermal deposit [7]. A big and deep fissure following the Cerna canyon is present and many transversal fissures exist. The thermal water springs are thus accompanied by large amounts of gases such as nitrogen and methane (which are the main components of emanated gases), helium and radon. Measurements in the Herculane Spa region have shown high helium $(5-10 \mathrm{ml} / \mathrm{L}[8,9])$ and $\operatorname{radon}\left(7.4 \mathrm{MBq} \cdot \mathrm{m}^{-3}\right)$ [10] concentrations.

The water of these deposits is permanently regenerated from three components [11]: a) uphill infiltration water from the Cerna Valley, b) deposit type water, and c) boiling hot deep water.

The methane system is one of the most investigated ion-molecule systems [12-14]. The presence of the upper homologues of methane $\left(\mathrm{C}_{2} \mathrm{H}_{6}, \mathrm{C}_{3} \mathrm{H}_{8}\right.$, etc. $)$ in gases near geothermal waters springs can be explained by the existence of the ion-molecule reactions. Theses reactions have as a starting point the $\mathrm{CH}_{4}{ }^{+}$ions that are formed after the impact with $\alpha, \beta$ radiation [10].

The existence of a high radioactivity level is due to the presence of uranium in the Cerna River valley area, which is confirmed by high radon activity and large helium concentrations in the studied gases (the source of nuclear radiations), which could be the factor responsible for initiating the ionmolecule reactions.

The presence of high radon activity as well as the presence of hydrogen at relatively high quantities leads to the suggestion that the apparition of the upper homologues of methane is a result of ion-molecule reactions. Radon activity was not previously identified as being at high levels in the Ghizela's Cross Spa and Mehadia coal mine [6]. The aim of the present research was to investigate and analyze the chemical composition of the gases emanated by the geothermal sources in Herculane Spa area, in order to explain the presence of high concentrations of helium.

\section{Experimental Section}

\subsection{Sampling of the Herculane Spa Area}

Twenty-four mineral waters sources are present in Cerna Canyon, in the Herculane Spa area (Băile Herculane, (C) 2000-2008, viewed 01 June 2008, available from: http://www.baile-herculane.ro/; Herculane's Spa Map (in Romanian), viewed 03 May 2008, Available from: http://www.ici.ro/ romania/en/turism/b_herculane1.html). The spas from Herculane Spa area display high radioactivity [7] and are comparable with the spas from Vichy (thermal springs, $46^{\circ} 07^{\prime} 40^{\prime \prime} \mathrm{N}$ and $3^{\circ} 25^{\prime} 36^{\prime \prime} \mathrm{E}$, Allier France) and Mont-Dore-les-Bains (thermal springs, 45 $35^{\prime} \mathrm{N}$ and $2^{\circ} 49^{\prime} \mathrm{E}$, Puy-de-Dôme - France). Almost sixty-seven percent of the spas are springs (sixteen out of twenty-four) and the other spas are 
drillings. The Herculane spas produce a total water flow of $65000 \mathrm{~L} / 24 \mathrm{~h}$. Due to the small debit, some of mineral water sources are not used any more.

Nine geothermal sources in Herculane Spa and the Mehadia coal mine were investigated (see Figure 1 and Table 1). The main criterion in the selection of the sources was a high debit of the emanated gases. The soil is of granite on the surface in the Ghizela's Cross Spa, Seven Hot Spas and Scorillo Spa areas. Granite covered by sedimentary rock soil is present otherwise. Radon flux is observed near the following spas: Ghizela's Cross, Scorillo, and Neptun 1.

Figure 1. Geothermal sources and gas measurement sites in the Herculane Spa area.

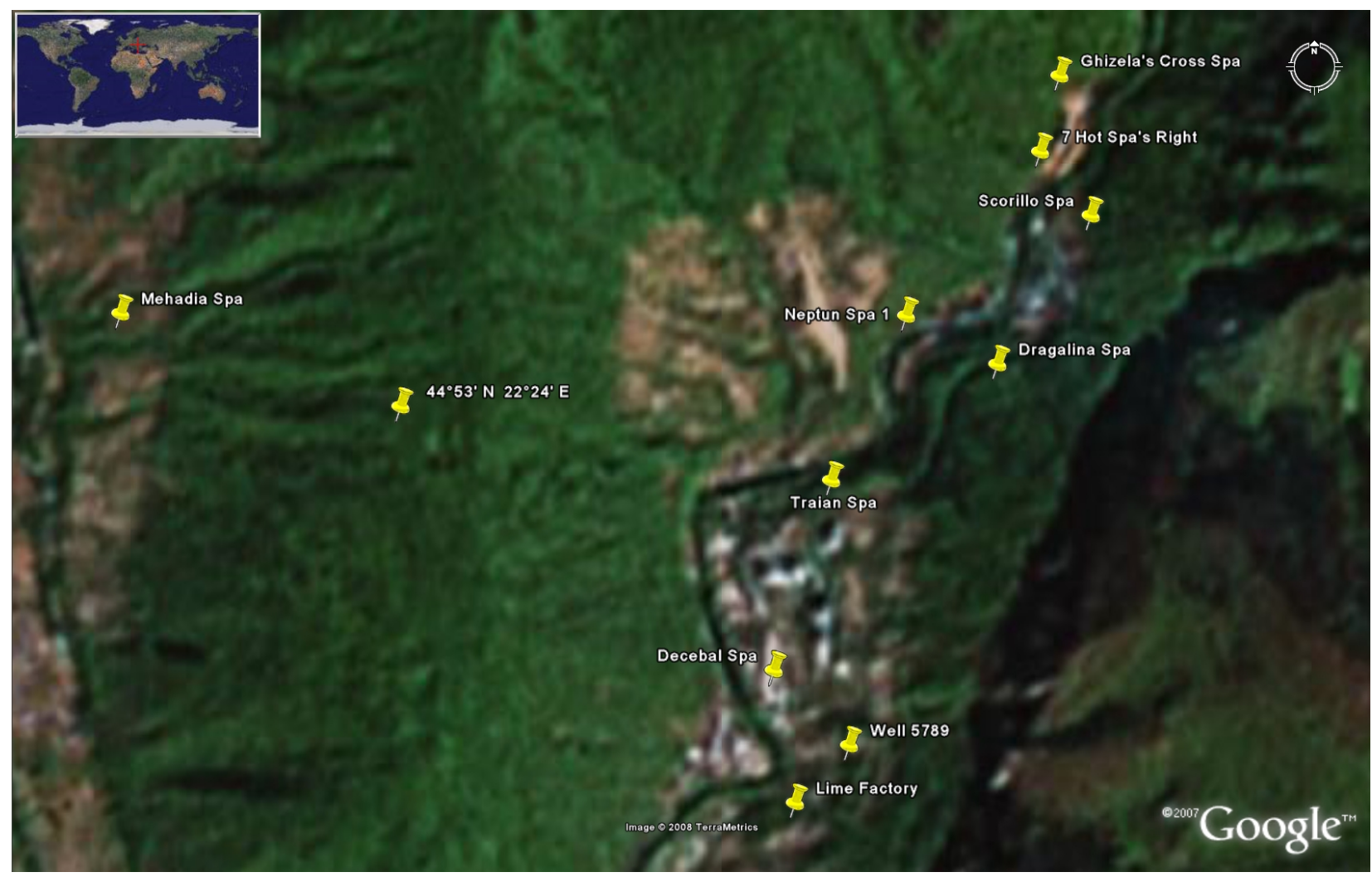

Table 1. Regions and locations: characteristics.

\begin{tabular}{llll}
\hline Name & Type & Latitude (North) & Longitude (East) \\
\hline Ghizela's Cross Spa & drilling & $44^{\circ} 53^{\prime} 31.35^{\prime \prime}$ & $22^{\circ} 25^{\prime} 28.29^{\prime \prime}$ \\
7 Hot Spas's Right & drilling & $44^{\circ} 53^{\prime} 24.14^{\prime \prime}$ & $22^{\circ} 25^{\prime} 25.70^{\prime \prime}$ \\
Scorillo Spa & drilling & $44^{\circ} 53^{\prime} 18.10^{\prime \prime}$ & $22^{\circ} 25^{\prime} 32.46^{\prime \prime}$ \\
Neptun Spa 1 & drilling & $44^{\circ} 53^{\prime} 8.59^{\prime \prime}$ & $22^{\circ} 25^{\prime} 7.73^{\prime \prime}$ \\
Dragalina Spa & spring & $44^{\circ} 53^{\prime} 4.00^{\prime \prime}$ & $22^{\circ} 25^{\prime} 19.95^{\prime \prime}$ \\
Traian Spa & drilling & $44^{\circ} 52^{\prime} 52.99^{\prime \prime}$ & $22^{\circ} 24^{\prime} 57.68^{\prime \prime}$ \\
Decebal Spa & drilling & $44^{\circ} 52^{\prime} 34.99^{\prime \prime}$ & $22^{\circ} 24^{\prime} 49.99^{\prime \prime}$ \\
Well 5789 & drilling & $44^{\circ} 52^{\prime} 27.87^{\prime \prime}$ & $22^{\circ} 25^{\prime} 0.08^{\prime \prime}$ \\
Lime Factory & drilling & $44^{\circ} 52^{\prime} 24.41^{\prime \prime}$ & $22^{\circ} 24^{\prime} 52.82^{\prime \prime}$ \\
Mehadia (coal mine) & - & $44^{\circ} 53^{\prime} 8.82^{\prime \prime}$ & $22^{\circ} 23^{\prime} 22.48^{\prime \prime}$ \\
\hline
\end{tabular}




\subsection{Methods used of Gases Collection}

The water springs and drillings carry high quantities of gases to the surface as gas bubbles. The gases bubbles are always in excess, compared with the dissolved gases [15]. Two special devices were designed, developed and used for sampling the gases, one for the springs and the other for drilling sources of thermal water (see Figure 2).

Figure 2. (a) Device for the sampling of the emanated gases from springs (1= metallic semi-sphere; 2 = metallic pipe; 3 = joint; 4 = gas flow). (b) Device for the sampling of the emanated gases from drilling $(1=$ metallic sphere; $2=$ metallic pipe; $3=$ metallic fixed flange; 4 = gasket; 5,6 = metallic interchangeable flanges; $7=$ screws for fixing flanges; 8 = joint; 9 = gas flow).
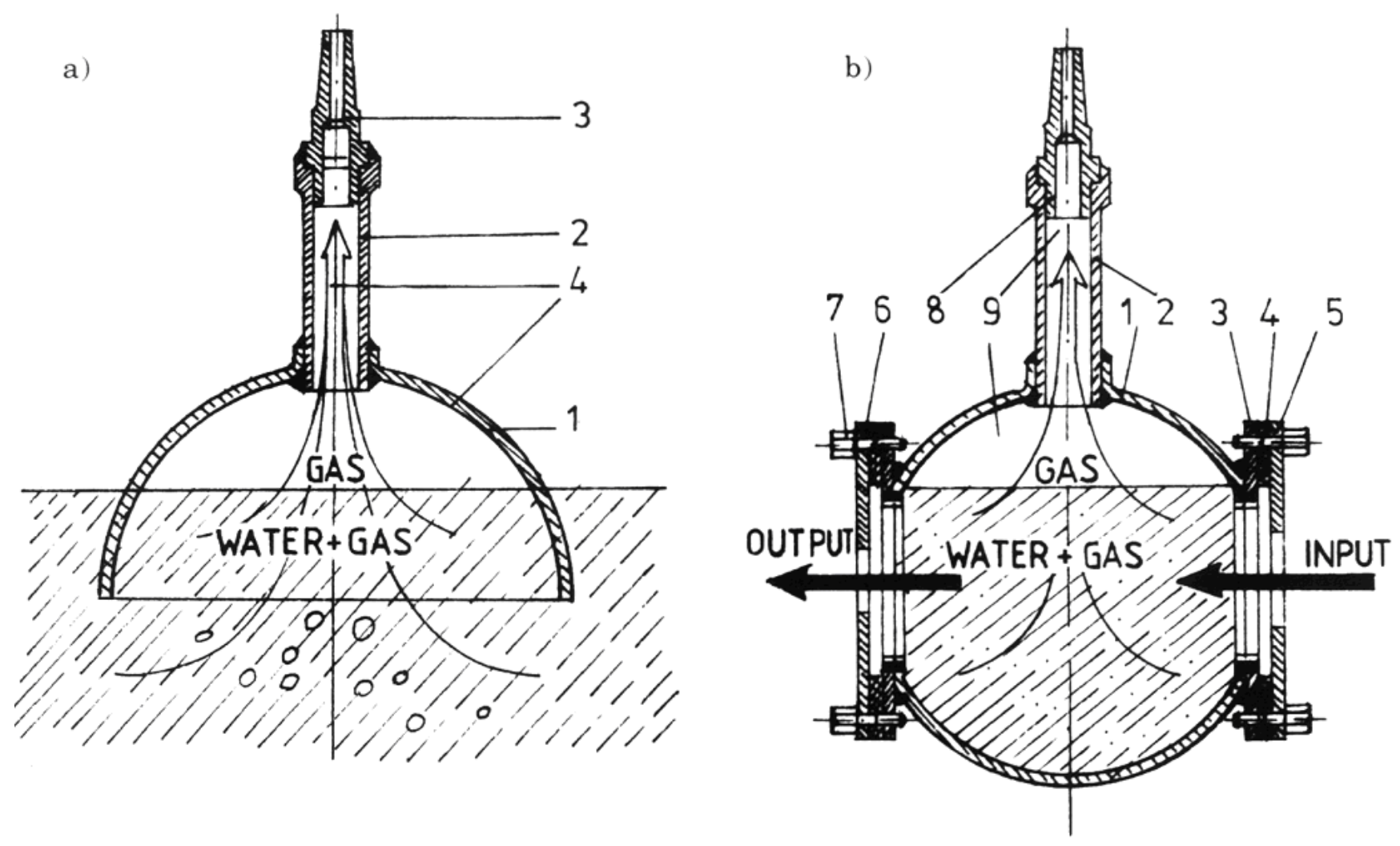

Some 6-7 km west of Herculane Spa, there is an important coal deposit organized on many levels, the last of these being deep coal shells (about 1,000-1,200 m). This coal deposit could be the methane source for the gases from the Herculane Spa geothermal sources. As it is well known, coal can contain large quantities of gases (up to $6-8 \mathrm{NTP} \mathrm{\textrm {m } ^ { 3 }} / 1,000 \mathrm{~kg}$ ). This was the reason for including the Mehadia coal mine in the analysis.

\subsection{Determination of Gases Composition}

The samples of gases from Herculane Spa were collected in October 1986. The determinations of the gases composition were done using a Dempster mass-spectrometer. Three measurements were performed at Babeş Bolyai University for each sample. 
Binary mixtures of different gases $\left(\mathrm{N}_{2}+\mathrm{CH}_{4} ; \mathrm{N}_{2}+\right.$ Ar; $\mathrm{N}_{2}+\mathrm{C}_{2} \mathrm{H}_{6}, \mathrm{CH}_{4}+$ Ar, etc.) were used as standards. The determination of a given gas concentration was done by comparing the mass peaks of standard with the mass peak of the sample [5].

\section{Results and Discussion}

The concentrations of the main constituents of the emanated gases from the investigated geothermal sources in Herculane Spa area and the gas composition of the gases extracted from the coal originating from Mehadia mine are presented in Table 2. The values represent the average of three determinations. The relative deviation between the measurements was of $5 \%$.

Table 2. Gas composition of emanated gases from Herculane Spa area.

\begin{tabular}{llllllllllll}
\hline \multirow{2}{*}{ No Location } & \multicolumn{8}{c}{ Gas concentration (\% volume) } & \multicolumn{3}{c}{$\left[\mathbf{C H}_{\mathbf{4}}\right] /$} \\
\cline { 2 - 8 } & $\mathbf{C H}_{\mathbf{4}}$ & $\mathbf{N}_{\mathbf{2}}$ & $\mathbf{C}_{\mathbf{2}} \mathbf{H}_{\mathbf{6}}$ & $\mathbf{A r}$ & $\mathbf{O}_{\mathbf{2}}$ & $\mathbf{S H}_{\mathbf{2}}$ & $\mathbf{C O}_{\mathbf{2}}$ & $\mathbf{H}_{\mathbf{2}}$ & {$\left[\mathbf{C}_{\mathbf{2}} \mathbf{H}_{\mathbf{6}}\right]$} \\
\hline 1 & Ghizela's Cross Spa & n.p. & 82.62 & n.p. & 1.47 & 14.73 & n.p. & 1.18 & n.p. & n.p. \\
2 & 7 Hot Spa's Right & 1.77 & 96.28 & 0.04 & 1.66 & 0.16 & 0.01 & 0.05 & n.p. & 44 \\
3 & Scorillo Spa & 2.87 & 95.12 & 0.16 & 1.73 & 0.12 & 0.04 & 0.07 & n.p. & 18 \\
4 & Neptun Spa 1 & 60.47 & 35.41 & 0.81 & 0.57 & 0.02 & 0.41 & 0.30 & 1.72 & 75 \\
5 & Dragalina Spa & 67.61 & 28.75 & 0.57 & 0.31 & 0.05 & 0.61 & 0.11 & 1.85 & 119 \\
6 & Traian Spa & 64.12 & 31.20 & 0.68 & 0.40 & 0.06 & 0.81 & 0.38 & 1.76 & 94 \\
7 & Decebal Spa & 70.88 & 25.54 & 0.84 & 0.47 & 0.04 & 0.15 & 0.08 & 1.98 & 84 \\
8 & Well 5789 & 64.77 & 32.13 & 0.60 & 0.36 & 0.02 & 0.01 & 0.02 & 1.68 & 108 \\
9 & Lime Factory & 59.51 & 37.06 & 0.69 & 0.60 & 0.15 & 0.03 & 0.66 & 1.43 & 86 \\
10 & Mehadia (coal mine) & 12.01 & 8.05 & n.p. & 0.17 & n.p. & 0.14 & 79.63 & 0.31 & n.p. \\
\hline
\end{tabular}

n.p. $=$ not present

The analyzed places could be classified in three groups according to the composition of emanated gases. First group contains a single thermal mineral drilling water source (Ghizela's Cross Spa, see Table 2). The gases identified in this first group could represent atmospheric gases that were processed underground, as suggested by a high oxygen content (14.73\%). The oxygen concentration decreased by almost $7 \%$ due to its reactivity in the underground route. Four out of eight investigated gases $\left(\mathrm{CH}_{4}\right.$, $\mathrm{C}_{2} \mathrm{H}_{6}, \mathrm{H}_{2} \mathrm{~S}$, and $\mathrm{H}_{2}$ ) were not identified in this source. The inert gases $\mathrm{N}_{2}$ and Ar were attached to the composition of emanated gases.

The second group contains one drilling and one spring source (Scorillo and 7 Hot Spa's Right, see Table 2). A high content of nitrogen (95.12\%, 96.28\% respectively), and a lower concentration of methane and ethane (less than 3\%) were measured for these sources. Contrary to the first source, oxygen was measured at a very low concentration ( $0.12 \%$ compared with $14.73 \%$ in the first group).

The third group comprises of sources in which the main constituent was identified as being methane. This group contains six sources (Neptun 1 Spa, Dragalina Spa, Decebal Spa, Well 5789, Traian Spa, and Lime Factory). A mass spectrum obtained from analysis a sample from Neptun 1 Spa 
is presented in Figure 3. The mass spectrum obtained for a Lime Factory sample is presented in Figure 4.

Figure 3. Mass spectrum: Neptun 1 Spa sample.

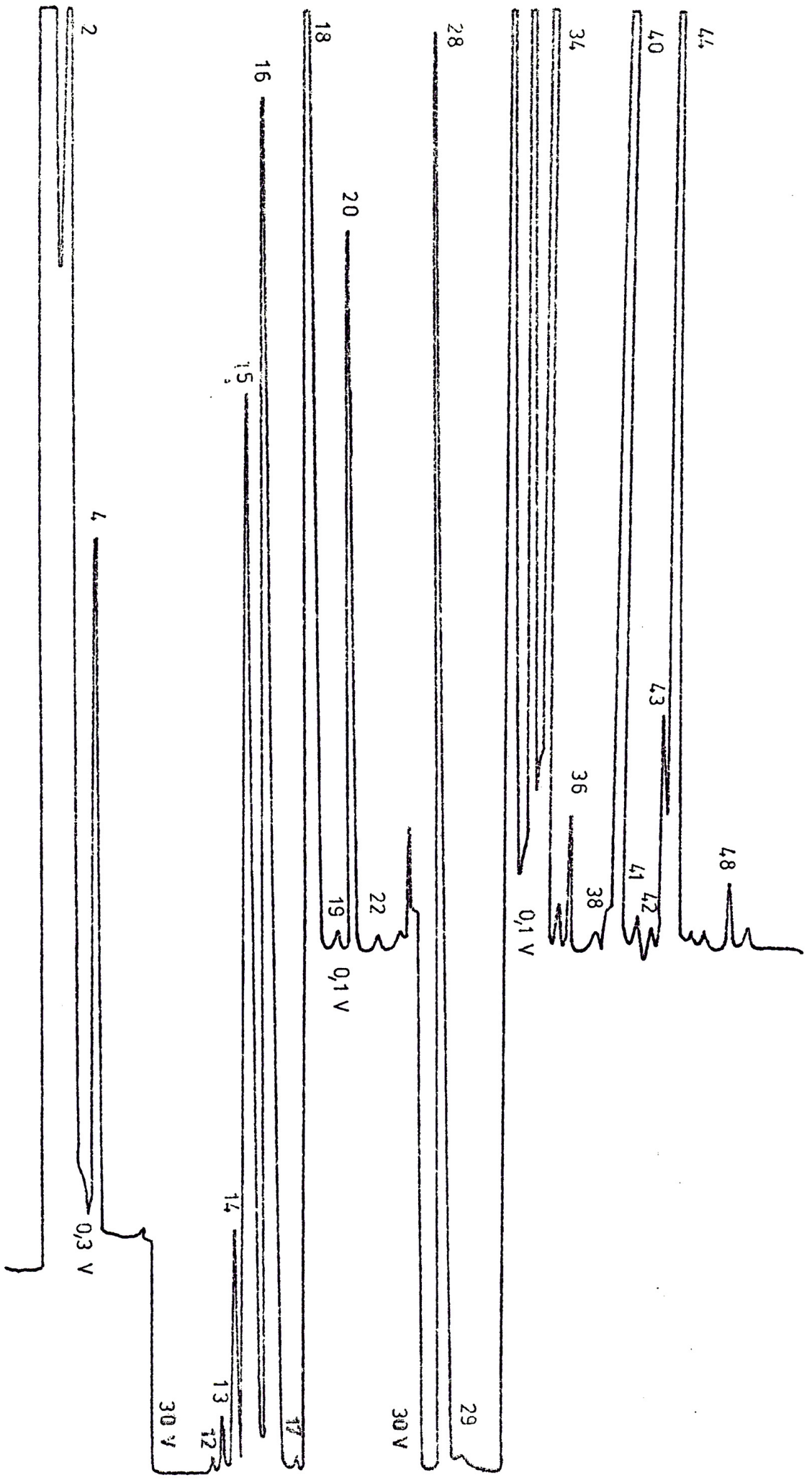


Figure 4. Mass spectrum: Lime Factory.

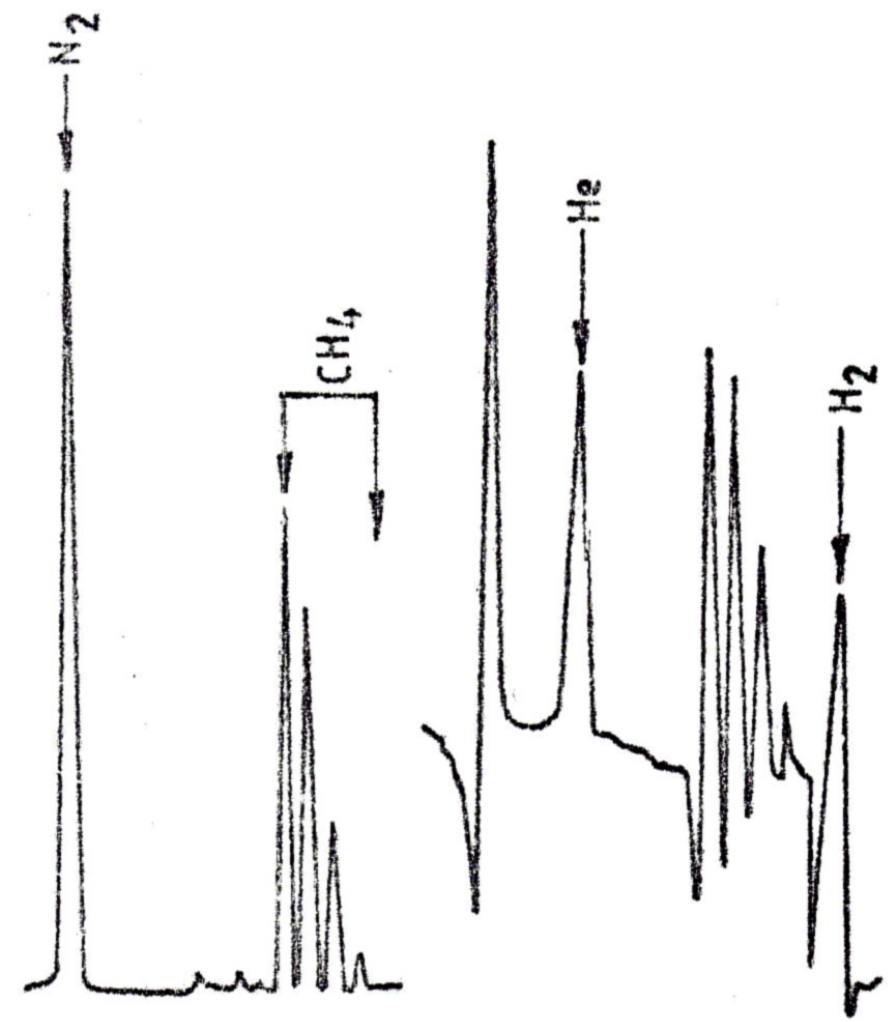

The concentration of methane varied from $59.51 \%$ (Lime Factory) to $70.88 \%$ (Decebal Spa). The ethane concentration reaches up to $0.84 \%$ in this group. A high concentration of helium has been previously reported from the sources of this group, the concentration of helium being the highest concentration in Romania [16]. Generally, the helium content follows the methane concentration. Lower concentrations of oxygen were identified in this group (with values from $0.15 \%$ found in Lime Factory to $0.02 \%$ found at Neptun and Well 5789 Spas). The hydrogen content was also high (up to $2 \%)$.

The last line of Table 2 (No. 10) presents the gas composition corresponding to the carbonnitrogen gases extracted from Mehadia coal mine. The main components in the Mehadia coal mine are $\mathrm{CO}_{2}(79.63 \%), \mathrm{CH}_{4}(12.01 \%)$, and $\mathrm{N}_{2}(8.05 \%)$. The concentrations of these gases are different from the others.

The main difference in the gas composition of the identified groups was in the level of methane, which was detected at high concentrations in the third group, compared with first and second ones. The low oxygen concentration in the second and third groups revealed the different origins of the gases in the investigated sources.

The atmospheric air geochemically processed by an underground route was slightly enriched with methane (migrated from the Herculane Spa) in the case of the first as well as the second group.

The gases identified in the third group of thermal mineral water sources are a mixture, in which the main component is the methane arising from the gases accumulated in the coal pores of Mehadia deep level deposit.

The presence of helium in these gases [5] and the classification of the geographical area as a high radioactivity zone [17] due to Cerna granites rocks sustain the following reaction mechanisms leading 
to $\mathrm{C}_{2} \mathrm{H}_{6}$ and upper homologues. The starting point is the $\mathrm{CH}_{4}{ }^{+}$ion, which appears as a consequence of uranium-radon (and its descendants) $\alpha$-attack.

The ion-molecule reactions of methane $[18,19]$ are:

$$
\begin{aligned}
& \mathrm{CH}_{4}^{+}+\mathrm{CH}_{4} \rightarrow \mathrm{CH}_{5}^{+}+\mathrm{CH}_{3} \\
& \mathrm{CH}_{4}^{+}+\mathrm{CH}_{4} \rightarrow \mathrm{C}_{2} \mathrm{H}_{4}^{+}+2 \mathrm{H}_{2} \\
& \mathrm{CH}_{4}^{+}+\mathrm{CH}_{4} \rightarrow \mathrm{C}_{2} \mathrm{H}_{6}^{+}+\mathrm{H}_{2}
\end{aligned}
$$

The $\mathrm{CH}_{3}{ }^{+}, \mathrm{CH}_{2}{ }^{+}$and $\mathrm{CH}^{+}$ions, forming the methane mass spectrum in the electron impact sources $(\alpha+\beta$ radiation in our case) can give the following reactions:

$$
\begin{aligned}
& \mathrm{CH}_{3}^{+}+\mathrm{CH}_{4} \rightarrow \mathrm{C}_{2} \mathrm{H}_{5}^{+}+\mathrm{H}_{2} \\
& \mathrm{CH}_{3}{ }^{+}+\mathrm{CH}_{4} \rightarrow \mathrm{C}_{2} \mathrm{H}_{3}^{+}+2 \mathrm{H}_{2} \\
& \mathrm{CH}_{3}^{+}+\mathrm{CH}_{4} \rightarrow \mathrm{C}_{2} \mathrm{H}_{4}^{+}+\mathrm{H}_{2} \\
& \mathrm{CH}_{2}^{+}+\mathrm{CH}_{4} \rightarrow \mathrm{C}_{2} \mathrm{H}_{3}^{+}+\mathrm{H}_{2}+\mathrm{H} \\
& \mathrm{CH}_{2}^{+}+\mathrm{CH}_{4} \rightarrow \mathrm{C}_{2} \mathrm{H}_{4}^{+}+\mathrm{H}_{2} \\
& \mathrm{CH}_{2}^{+}+\mathrm{CH}_{4} \rightarrow \mathrm{C}_{2} \mathrm{H}_{2}^{+}+2 \mathrm{H}_{2} \\
& \mathrm{CH}^{+}+\mathrm{CH}_{4} \rightarrow \mathrm{C}_{2} \mathrm{H}_{2}^{+}+\mathrm{H}_{2}+\mathrm{H}
\end{aligned}
$$

The secondary ions that appeared in reactions from $\mathrm{Eq}(4)$ to $\mathrm{Eq}(10)$ can subsequently give the following reactions:

$$
\begin{aligned}
& \mathrm{C}_{2} \mathrm{H}_{3}^{+}+\mathrm{CH}_{4} \rightarrow \mathrm{C}_{2} \mathrm{H}_{4}^{+}+\mathrm{CH}_{3} \\
& \mathrm{C}_{2} \mathrm{H}_{3}{ }^{+}+\mathrm{CH}_{4} \rightarrow \mathrm{C}_{3} \mathrm{H}_{3}^{+}+\mathrm{H}_{2}+2 \mathrm{H} \\
& \mathrm{C}_{2} \mathrm{H}_{3}^{+}+\mathrm{CH}_{4} \rightarrow \mathrm{C}_{3} \mathrm{H}_{4}^{+}+\mathrm{H}_{2}+\mathrm{H} \\
& \mathrm{C}_{2} \mathrm{H}_{3}^{+}+\mathrm{CH}_{4} \rightarrow \mathrm{C}_{3} \mathrm{H}_{5}^{+}+2 \mathrm{H} \\
& \mathrm{C}_{2} \mathrm{H}_{3}^{+}+\mathrm{CH}_{4} \rightarrow \mathrm{C}_{3} \mathrm{H}_{5}^{+}+\mathrm{H}_{2} \\
& \mathrm{C}_{2} \mathrm{H}_{3}^{+}+\mathrm{CH}_{4} \rightarrow \mathrm{C}_{3} \mathrm{H}_{6}^{+}+\mathrm{H} \\
& \mathrm{C}_{2} \mathrm{H}_{4}^{+}+\mathrm{CH}_{4} \rightarrow \mathrm{C}_{3} \mathrm{H}_{7}^{+}+\mathrm{H}
\end{aligned}
$$

The cross section of these ion-molecule reactions is a function of the kinetic energy of molecular ions that increases when kinetic energy decreases [20]. At very small kinetic energies (thermal energy range), the reaction from $\mathrm{Eq}(17)$ is likely to produce propane directly:

$$
\mathrm{C}_{2} \mathrm{H}_{4}^{+}+\mathrm{CH}_{4} \rightarrow \mathrm{C}_{3} \mathrm{H}_{8}^{+}
$$

The reactions presented in $\mathrm{Eq}(1)-\mathrm{Eq}(18)$, occurring on a thermal energy range and initiated by $\mathrm{CH}_{4}{ }^{+}, \mathrm{CH}_{3}{ }^{+}, \mathrm{CH}_{2}{ }^{+}, \mathrm{CH}^{+}$ions, are attributable to nuclear radiation $(\alpha$ and $\beta$ ). They can explain the appearance of upper methane homologues and the presence of hydrogen in the gases from the dry methane group, which migrates also in the gases from the Lime Factory resort. 


\section{Acknowledgements}

The research was partly supported by the UEFISCSU Romania through Research Grant ET/108/2006.

\section{References}

1. Simion, G.; Ponta, G.; Gaspar, E. Dynamics of Underground Waters from Băile Herculane, Cerna Valley (Romania). Ann. Soc. Geol. Belg. 1984, 108, 245-249.

2. Raileanu, B.; Băican, I.; Rădulescu, G. Possibilities in rehabilitation of inflammatory rheumatism in Herculane spa. Zeitschr. f. Physiother. 1982, 34, 91-95.

3. Franko, O. Piest'any-thermal H2S water and mud. Environ. Geol. 1998, 36, 215-218.

4. Coiro, V.; Irali, L.; Saccani Jotti, G.; Varacca, G.; Danesino, V. The therapy of gynaecological diseases with salty mineral water: A branch of the "Naiade Project". Ital. J. Gynaecol. Obstet. 2003, 15(2), 88-94.

5. Chiarini, A.; Dal Pra, I.; Pacchiana, R.; Zumiani, G.; Zanoni, M.; Armato, U. Comano's (Trentino) thermal water interferes with interleukin-6 production and secretion and with cytokeratin-16 expression by cultured human psoriatic keratinocytes: further potential mechanisms of its antipsoriatic action. Int. J. Mol. Med. 2006, 18, 1073-1079.

6. Băican, I.; Raibulet, A.; Raibulet, T. Rehabilitation of posttraumatic patients in Herculane spa. Zeitschr.f. Physiother. 1982, 34, 103-109.

7. Cosma, C.; Ristoiu, D.; Poffin, A. Indoor radon and radon emanation in the Herculane Spa (Cerna valley) area-Romania. Ind. Built Environ. 1996, 5, 236-240.

8. Mastan, I. Helium in Geothermal Water Sources; Ph.D. Thesis, University Babes-Bolyai, ClujNapoca, Romania, 1987; pp. 34-35.

9. Cosma, C.; Ristoiu, D. Study of rare gases in geothermal waters from Herculane area, Romania. Nuovo Cim. Soc. Ital. Fis. C 1999, 22(3-4), 317-323.

10. Cosma, C.; Ristoiu, D.; Poffijn, A.; Meesen, G. Radon in various environmental samples in the Herculane Spa, Cerna Valley, Romania. Environ. Int. 1997, 22, S383-8388.

11. Visarion, M.; Apostol, A.; Ştefanescu, R. Contributions to explanation of geothermal deposit from Herculane Spa. Stud. Cercetări Geofizică 1974, 12, 135-140.

12. Hand, C.W.; Weyssenhoff, H. Ion-Molecule Reactions Studied by Time-of-Flight Mass Spectrometry. Can. J. Chem. 1964, 42(1), 195-197.

13. Abramson, V.P.; Futrel, J.V. Ion-Molecule Reactions of Methane. J. Chem. Phys. 1966, 45, 19251931.

14. Brehm, B.; Eland, J.H.D.; Frey, R.; Schulte H. Branching ratios and kinetic energies in unimolecular ion dissociations - propane and neopentane. Int. J. Mass Spectrom. Ion Phys. 1976, 21, 373-379.

15. Etiope, G.; Guerra, M. Gas-water partition and gas channeling along Rn-He-CO2 bearing faults. Nuovo Cim. 1999, 22, 369-372.

16. Cosma, C.; Mastan, I.; Znamirovschi, V.; Cozar, O. Radioactivitatea gazelor naturale emanate din sursele de ape minerale şi geotermale din Carpaţii Orientali. Stud. Cerce. Fiz. 1985, 37, 139-145. 
17. Cosma, C. Studii asupra radioactivităţii şi compoziţiei chimice a gazelor naturale emanate din surse de ape minerale şi geotermale; PhD Thesis, Babes-Bolyai University, Cluj-Napoca, Romania, 1986; pp. 43-68 (in Rumanian).

18. Haynes, R.M.; Kebarle, P. Mass-Spectrometric Study of Ions at Near-Atmospheric Pressure. The AlphaRadiolysis of Methane. J. Chem. Phys. 1966, 45, 3899-3906.

19. Golam Rasul, G. K. Surya Prakash, and George A. Olah. Comparison of structures and energies of $\mathrm{CH} 52+$ with $\mathrm{CH} 4+$ and their possible role in superacidic methane activation. Proc. Nat. Acad. Sci. USA 1997, 94, 11159-11162.

20. Lindholm, E. Ion - Molecule Reactions; Plenum Press: New York, 1972.

(C) 2008 by the authors; licensee Molecular Diversity Preservation International, Basel, Switzerland. This article is an open-access article distributed under the terms and conditions of the Creative Commons Attribution license (http://creativecommons.org/licenses/by/3.0/). 